\title{
Impact of Income Taxes on Wages. A Non Parametric Analysis of the Mexican Case by Gender
}

\author{
Linda Irene Llamas Rembao \\ Centro de Investigación en Alimentación y Desarrollo (CIAD), México \\ Luis Huesca Reynoso ${ }^{1}$ \\ Centro de Investigación en Alimentación y Desarrollo (CIAD), México \\ Université Laval, Canada \\ José Javier González \\ Universidad de Sonora (UNISON), México \\ (Primera recepción: 20/septiembre/2017, última recepción: 18/mayo/2018, \\ aceptado: 14/septiembre/2018)
}

\section{Abstract}

The objective of this work is to measure the effect of income tax on wages in Mexico with respect to gender and working hours. A microsimulation of the tax burden of formal wage earners was carried out, using a non-parametric method to avoid assuming a functional relationship of variables through the use of the Gaussian kernel function. The results show that the tax burden only falls on $60 \%$ of salaried employees. Men bear a higher tax burden than women and an increase in working hours does not cause a significant increase in the payment of the tax. It is recommended to establish strategies in favor of better salaries that allow an increase in collection. The limitation of the study is that it does not consider the incidence of corporate or self-employed taxes. The originality of this is to offer an alternative measure of income tax considering wages and working hours without establishing a priori conditions between them. The conclusion is that a low-wage labor market will not contribute to the strengthening of public income.

JEL Classification: H22, H24, J31, C14, H23

Keywords: Tax burden, Income taxes, Wages, Non-parametric analysis, Redistribution

\section{Impacto de los impuestos al salario. \\ Un análisis no paramétrico del caso de México por Género}

\section{Resumen}

El objetivo del trabajo es medir el efecto del impuesto sobre la renta en los salarios en México en función del sexo y las horas trabajadas. Realizamos microsimulación de la carga impositiva de los asalariados formales y utilizamos un método no paramétrico para evitar asumir una relación funcional de las variables, mediante el uso de la función kernel Gaussiana. Los resultados muestran que la carga impositiva solo recae en el 60 por ciento de los asalariados. Los hombres soportan una mayor carga tributaria que las mujeres y un aumento en las horas de trabajo no causa un aumento significativo en el pago del impuesto. Se recomienda establecer estrategias a favor de mejores salarios que permita incrementar la recaudación. La limitante del estudio es que no considera la incidencia de impuestos de sociedades o trabajadores por cuenta propia. La originalidad es ofrecer una medición alternativa del ISR teniendo en cuenta los salarios y las horas de trabajo sin establecer condiciones a priori entre ellos. Se concluye que un mercado laboral de bajos salarios no contribuirá al fortalecimiento de los ingresos públicos.

\footnotetext{
${ }^{1}$ Corresponding author. Address: Carretera a La Victoria km 0.6, Hermosillo, Sonora, México, C.P. 83304. Phone number: 52+662-289 2400 ext. 371. E-mail: lhuesca@ciad.mx

* Sin fuente de financiamiento declarada para el desarrollo de la investigación
} 


\section{Resumen}

Clasificación JEL: H22, H24, J31, C14, H23

Palabras clave: Carga fiscal; Impuestos directos; Salarios; Análisis no paramétrico, Redistribución

\section{Introducción}

Tax systems in Latin American countries are characterized for having a low tax collection with respect to their level of development. According to information by the Economic Commission for Latin America and the Caribbean (ECLAC) in 2013 Chile, Mexico, Panama, the Dominican Republic and Venezuela showed the widest gap with respect to the world's average. Meanwhile, from 2000 to 2014 Argentina, Bolivia, Brazil, Ecuador and Nicaragua stood out for having improved their tax collection as a percentage of their GDP. By comparison Mexico only grew its tax collection by merely 3 percentage points of its GDP, among the lowest in the group. Thus, ECLAC recommends implementing a series of structural reforms to the tax system, direct and indirect, to reinforce the tax collection in most Latin American countries (ECLAC, 2016).

The tax system implemented in Mexico in 2014 seeks to lower its dependency on oil revenues while improving its tax structure in order to make it more equitable. That is, a better distributed tax burden such that equals are treated equally (Musgrave, 1990). The addition of new income tax rates to people earning over 750 thousand pesos seeks to make the tax system more equitable. According to the estimates made by Mexico's internal revenue service (SHCP, by its initials in Spanish) for 2016, this would impact the top 1 percent while leaving the remaining 99 percent unaffected.

Mexico's fiscal system gets most of its tax revenues from the income tax. In 2014 it represented 53 percent which is 5.56 percentage points of the GDP. Out of that revenue stream, 49 percent comes out of taxes seized from wage earners and 51 percent comes from taxes seized from companies, which are 2.74 and 2.82 percentage points of the GDP respectively. Tax collection from personal income grew by 19.39 percent from 2012 to 2014 . Wage earners were the tax-base with a largest increase during this period, registering a 25 growth in tax payments. Meanwhile tax revenue coming from companies grew by merely 14 percent (SHCP, 2016).

But with the low wage levels in Mexico, and by concept of direct taxes, is the current tax system's fiscal structure adequate for current incomes? Specifically, does the new personal income tax scheme have an impact in labor? To wit, do these structural changes translate into more equitable tax burdens in terms of wage levels or hours worked? Our research estimates the effect of the income tax on wages.

Unlike the literature on personal income tax incidence, this study offers an alternative non-parametric measure, without setting a priori conditions between variables and letting the data speak by itself. The use of non-parametric approach avoids to assume any sort of functional relationship, letting the data provide evidence regarding the response between the tax burden and the different groups of taxpayers. Thus, the purpose is to measure the effect of income taxes on wages for Mexico differentiating workers by sex and hours worked. Also, we reveal the extent of low wage earners receiving an earned income tax credit in Mexico. We find that only 60 percent of wage earners earn enough income to pay income taxes without any tax credit while almost 40 percent of the workforce is unable to pay their full tax share. Our calculations reveal that men bare a greater burden than women when faced with the marginal rates in the new tax structure.

Our work is presented in the following order. The next section shows a review of national and international research literature relevant to the study of direct taxation. The following section explains the model and theoretical framework of our work as well as 
the mathematical derivation of our functioning estimates. The fourth section shows the empirical application and the results of our study. In the fifth and final section we present our concluding remarks and recommendations.

\section{Literature Review}

The prevailing research literature has focused on the analysis of the progressiveness of direct taxation considering income among other relevant figures such as social security and transfers taking into account its impact on horizontal inequity - i.e., a fiscal system that treats equal taxpayers unevenly (Musgrave, 1990). On the other hand, research on labor participation linked to the tax-burden on income are described in detail in recent papers from surveys on the topic such as Keane (2011) as well as that of Mastrogiacomo et al (2017).

The role exerted by income taxation and the international tax-burden

Recent studies on the effect of taxes on Canada's taxpayers has pondered four central aspects: (1) the income tax, (2) household subsidies and government tax credits, (3) intergenerational transfers and social welfare, and (4) unemployment benefits. Using data from Canada's consumer finances from 1991, studies by Duclos and Tabi (1996) and Davidson and Duclos (1997) estimated an index of progressiveness focusing on tax redistribution. This index evaluates the progressiveness of Canada's fiscal system as a whole, taking into consideration the effect of taxes and transfers - income being one of the most progressively taxed components in Canada.

Perrote, Rodríguez and Salas (2002) estimated the horizontal inequity of the income tax on Spain's taxpayers. They found that from 1988 to 1995 the effect of direct taxes and the total redistribute effect of the fiscal system where crucial in the increase of welfare of the citizenry. They illustrate the importance of direct taxation upon redistribution among the different cohorts of taxpayers, as well as the importance of having a more efficient method of tax collection.

Comparative studies among different countries show the effects of income distribution among different types of taxpayers and households (OECD, 2005; Joumard, Pisu and Bloch, 2012; Paturot, Mellbye and Brys, 2013; Lustig, Pessino and Scott, 2014; ECLAC, 2016; Castañeda, 2016). Overall, they show that the tax rate along with the system of transfers reduces vertical inequity of income redistribution among most members of the Organization for Economic Cooperation and Development (OECD). These studies claim that a more redistributive tax system leads to higher levels of tax collection. Paturot, Mellbye and Brys (2013) analyze the progressiveness of payroll taxes for 34 OECD countries and consider the effect of direct taxes upon five intervals of wage income - i.e., between 50 and 200 percent of each country's mean wage. According to their results tax rates are more progressive among the lower income levels, decreasing along higher levels.

According to Lustig, Pessino and Scott (2014), the tax and transfers systems in countries like Argentina, Brazil and Uruguay show a decrease in inequality and poverty. Meanwhile, countries like Mexico, Bolivia and Peru show a decreased redistributive effect as a result of a low collection of income tax with respect to their GDP in spite of their progressive direct taxes. Similarly, ECLAC (2016) points out that tax revenues from direct taxation are insufficient to have a significant impact on redistribution. Additionally, the personal income tax in Latin-American countries averaged 1.3 percent of the GDP in $2011^{2}$, less than one fifth of the OECD average ( 8.5 percent). The effective tax rate of personal income in Latin America is also distinctively low (2.3 percent) with a diminished effect on the reduction of inequality - i.e., -2.1 points of the Gini coefficient. By comparison the average effective tax rate in OECD countries is 13.3 percent, reducing inequality

\footnotetext{
${ }^{2}$ Except Cuba and Haiti.
} 
by -11.6 points (ECLAC, 2016: 104-105).

In contrast Castañeda (2016) claims that for revenues purpose the efficiency of the personal income tax has gone hand-in-hand with Latin America's opening up to trade as well as a low (personal income) tax burden. Castañeda also provides evidence showing countries in Latin America relied on a greater burden upon indirect taxation - i.e., Value Added Tax - rather than personal income taxes to fund an increase in government spending to afford greater coverage for health and education.

Rodriguez (2014) showed a decrease in the informal sector of Colombia's economy as a result of a reduction in tax rates - especially in income taxes. He suggests that after 20 years of implementing reduction in rates employment would grow by 2.93 percent. Thus the informal sector would decrease at a rate of 9.02 percent, from 39.1 to 35.57 percent of GDP. Rodriguez proposes an income tax of 24.5 percent, calibrated as a simple average of the effective marginal tax rates in Colombia. This level is similar to that of Mexico circa 2002. Since, there has been a decrease in the effective marginal tax rates in Mexico to 18 percent in recent years (Huesca and Araar, 2016).

According to some studies, Mexico's tax system as a whole is progressive. Their empirical evidence over three decades (1984-2014) shows that unlike revenue from indirect taxes, revenue from direct taxes bestow progressiveness upon its tax system (Vargas, 2010; Scott, 2014; Huesca and Araar, 2016). These studies have also attributed a limited redistributive impact on the tax system due to low tax productivity, multiple exemptions and inefficient collection (Scott, 2014; Huesca and Araar, 2016).

Relevant research on the labor and income-taxation.

The role of labor and its burden on the fiscal system has been an issue of remarkably relevance. For instance, Keane (2011) surveys the topic and he focuses on implications for effects of wages and taxes separating the effects by sex. His research study this relationship considering the output of a literature from a three-behavior perspective: static models, lifecycle with savings, as well as life-cycle models with both savings and human capital. When separating the women, variables of fixed costs among demographics like fertility or marriage interacting with human capital.

Considerable controversy can be found in the literature over labor supply and its response to changes in wages and taxes, where at least for males, Keane (2011) confirms small estimates for labor supply. Elasticities, once corrected for these controls become greater. Then, the previous study explains a faster reaction in the labor market for women, whether to decide work more or to be able to pay a greater share of the income tax-burden than men. Finally, the elasticities for workers become greater for women than for men.

Another important study from Mastrogiacomo et al (2017) presents how responsive are the jobs in Netherlands with respect to income taxation as well as other benefits. Main findings show differences in labor supply responses between households with and without children are much bigger than those presented in the literature. An efficient taxbenefit system should be taken into account for the substantial heterogeneity in behavioral responses to labor market participation. On the contrary, in Germany the study of Hayo and Uhl (2015) reveals that gender does not have a significant influence on labor market participation when payroll tax change, but it is relevant for self-employed labor supply decisions.

After reviewing several empirical evidence, Meghir and Phillips (2010) found that there is a consensus on annual labor supply elasticity for women close to 1; however, when weekly hours are considered for estimates, the elasticities tend to be quite small (ranges from 0.0 to 0.3). According to generalized belief, women are more responsive to incentives -which implies that they respond more to tax changes-, the authors concludes that the effect of tax changes on women's hours worked (particularly married women and lone mothers) is slightly stronger than it is for men. 
Also, wage subsidies (such as EITC program) have consequences on labor supply. Empirical literature has documented generally positive impacts such as: growth of net incomes for low-income families and improvement on children wellbeing; also, the decline on labor participation from married women is offset by the rise in participation of single mothers (Nichols and Rothstein, 2015). However, in the United States (US) labor force participation rate in response to the EITC expansions in the US subsidizes make married women to stay at home (Eissa and Williamson, 2004). Despite this, EITC is highly effective as an antipoverty policy, since most of the credit recipients in the United States (US) were either below the poverty line or led to close the poverty gap; hence, EITC is considered as the largest cash or near-cash transfer for low income households in the US (Scholz, 1994). For those reasons, EITC expansions has been of high interest for fiscal policy makers.

For the Mexican case, Alberro (2018) proposes a negative income tax (NIT) to eradicate chronic poverty and decrease income inequality (which is an EITC-like program). Eligibility criteria for working population aged above 18 years old with total incomes under certain threshold (which considers two parameters: poverty line and income poverty gap). Also, NIT encourages workers to increase their income. According to author's estimates, the NIT fiscal cost represent $1.25 \%$ of GDP.

As a review conclusion in the literature.

The review of the current literature on income taxation and labor participation allows us to have a nicely picture of what is going on with the effort of combining, good or bad jobs linked to the burden exerted through a fiscal system. In general we can conclude that:

- A limited redistributive impact on tax systems is registered due to low tax productivity, multiple exemptions and inefficient collection from the public revenues.

- Personal income tax has gone hand-in-hand with Latin America's opening to international trade where a decreasing pattern on income-tax burden was found.

- A shift towards a tax collection system mostly funded by indirect taxes can be observed.

- Higher female labor participation with tax payments of higher fiscal pressure, even when its counterpart tends to work less and less hours too.

- EITC programs are effective as an antipoverty policy, even though different response on labor force participation by gender is observed.

\section{Model and determinants of the willingness to work and pay taxes}

In order to determine the income tax payments levied upon wage earners we develop a theoretical model based upon a simple deterministic fiscal system. We express said system as the sum of the net wage $(\mathrm{N})$ plus taxable income payments $(\mathrm{T})$ and contributions to social security payments (SSC), forming an equation to describe the gross wage of workers $(\mathrm{X})$ as: ${ }^{3}$

$$
X=N+T+S S C
$$

We assume each worker faces a tradeoff between higher wages and less leisure, or more hours worked. The dilemma of the representative worker between an implied increase in

\footnotetext{
${ }^{3}$ Although deductions and exemptions described in Mexico's income tax law are not applicable to this study given: (1) the difficulty of distinguishing the expenditures a tax payer would prefer to deduce according to survey answers; and (2) if it was even possible to do so, it would require making assumptions about the deductible amounts allowed by law.
} 
tax burden upon an increase in wages can be represented under a simple utility function. We specify a utility function $U_{i j}(C, H, X)$ for worker $i \in\{1,2, \ldots, n\}$ of gender $j \in\{1,2\}-$ i.e., $j=1$ represents women - where $C$ represents the consumption of a basket of goods, $H$ represents hours labored, and $X$ represents the worker's gross wage given a tax burden $T^{4}$. The utility function of worker i will be affected by his or her tax burden $T$ upon his or her wage income $X_{i j}$. Thus, we likewise represent this direct taxation burden $T(X)$ upon workers under the corresponding tax brackets and law, such that:

$$
T=X-N-S S C
$$

where $N$ is the net disposable income and SSC standing for the social security contributions. We formulate a hypothesis stating that, for a rational worker with ordered preferences an increase in working hours does not necessarily imply a greater tax burden, and male workers bare the brunt of the tax burden in the fiscal system. For the purposes of this model, there are constant returns to scale between the amounts of hours worked and wages. That is, additional hours worked are paid at the same wage rate.

\subsection{A non-parametric method of analysis}

The usual empirical approach analyzes agent behavior through a demand schedule with its corresponding elasticities to estimate the marginal efficiency of any given tax. Instead, we employ non-parametric techniques to allow the data to 'speak for itself' and minimize the effect of outliers in the distribution of income upon our observed results (Duclos and Araar, 2006, 267)..$^{5}$

Theorem 1. There is a weighted kernel of the form $K\left(\frac{X-X_{i}}{h}\right)$ given a differentiable and continuous kernel density function that one may reduce the bias among "neighboring" individuals in the data near the $T_{i}^{\prime} s$, inversely proportional to the distance $X-X_{i}$ such that $n h^{0,5}(\hat{m}(X)-m(X))$, where $n h^{-0,2}$ is the bandwidth between the data and the band $h \rightarrow 0$ and $n h \rightarrow \infty$ when $n \rightarrow \infty$, where the conditional variance of the tax burden is given by (See Härdle, 1990, Proposition 3.1.1).

As follows, in definition 1 we explain why a Gaussian kernel function is preferred in our empirical application.

Definition 1. The definition of the estimator function $\hat{f}\left(T_{i}\right)$ takes into account the properties of continuity and differentiability of the kernel estimator function $K(u)$. For the sake of convenience a kernel function that is symmetric for values near zero is selected, with $\int K(u) d u=1, \int u K(u) d u=0$ and $\int u^{2} K(u) d u=\sigma_{K}^{2}>0$ This Gaussian type function meets the inherent properties described in this definition, and has the form:

$$
K(u)=2 \pi^{-0,5} \exp ^{-0,5 u^{2}}
$$

Proof 1. The "noise" in this Gaussian distribution has the traditional bell-shape and is easily differentiable at any desirable level, with a rate of convergence guaranteed to reach $\sigma_{K}^{2}=1$. Proof 2 . Thus we can differentiate (3) and add $h$ so to rewrite the expression for the Gaussian kernel estimator:

\footnotetext{
${ }^{4}$ While the amount of labor, or hours worked, is considered something undesired or a bad, we opted to use this metric instead of the amount of hours for leisure - i.e., (24 - H). This allows us to simultaneously measure the effect of a marginal change in wages upon a wage earner's willingness to work as well as the effect of an increase in taxation upon said earner's willingness to work for those wages.

${ }^{5}$ Instead of defining the dependent variable as a function of independent variables and parameters with known distributions, non-parametric techniques allow us to forgo any assumption about the "representative" household or economic agent in the sample. To wit, instead of assuming certainty on the average of the parameters, non-parametric methods allow us to infer through rigorous sampling with replacement of the entire data.
} 


$$
K(u)=\frac{1}{h \sqrt{2 \pi}} \exp \left(-0,5 \lambda_{i}(u)^{2}\right)
$$

where $-0,5 \lambda_{i}$ is a factor of convergence to the real values.

We introduce the non-parametric estimation for the tax burden, $T_{i}$, as the predicted response to the income tax in the term $m\left(X_{i}\right)$, such that: ${ }^{6}$

$$
T_{i}=m\left(X_{i}\right)+\varepsilon_{i}, \text { where } E\left(\varepsilon_{i}\right)=0
$$

The function $m\left(X_{i}\right)=E\left[T_{i} \mid X_{i}\right]$ overcomes the empirical inability of observing a direct and linear response of the tax rates upon $X_{i}$ that can explain the functional and deterministic form of the tax burden recorded in $T_{i}$. We calculate an estimate using a local non-parametric regression that connects the $m$ points with Theorem 1 and expression (5), employing ordinary least squares without the need of an a priori specification to imply a functional relation. Thus the tax burden can be estimated using $\hat{f}\left(T_{i}\right)$ as the Gaussian kernel function $K_{i}(X)^{0,5} T_{i}$ such that: ${ }^{7}$

$$
K_{i}(X)^{0,5} T_{i}=\alpha(X)^{0,5}+{ }_{i}(X)^{0,5}\left(X_{i}-X\right)+\varepsilon_{i}
$$

where $\alpha, \beta$ are the coefficients for the constant term and the estimated parameter, respectively, $X_{i}$ represents worker $\mathrm{i}$ gross wages and $\varepsilon_{i}$ is a term of randomness. The estimated density function of the tax burden hatf $\left(T_{i}\right)$ is represented by the estimator $K_{i}$, as described in (6) under the conditions previously established in Proof 2 . From the equation in (6) we get the estimators for $T=T_{i}(X)+\varepsilon_{i}$ as well as $T=T_{i j}(H)+\varepsilon_{i}$, with their respective predictions given by:

$$
\begin{gathered}
E\left[T_{i} \mid X_{i}\right]=\beta_{i} \\
E\left[T_{i j} \mid H_{i j}\right]=\gamma_{i j}
\end{gathered}
$$

We use the first partial derivatives to estimate the marginal income tax rates with respect to gross wage levels, a non-parametric conditioning of the form:

$$
E\left[\frac{d T_{i}}{d X_{i}} \mid X_{i}\right]=\beta_{i}^{\delta}
$$

Similarly we use first partial derivatives to estimate marginal income tax rates with respect to hours worked. This non-parametric conditioning measure intends to capture the marginal utility of an individual's wage with respect to tax payments, using hours worked to register this procedure for the worker's sex:

$$
E\left[\frac{d T_{i}}{d H_{i j}} \mid H_{i j}\right]=\gamma_{i j}^{\delta}
$$

These conditions let us identify which groups have been somewhat affected in a progressive manner with respect to their tax burdens and hours worked.

\subsection{A non-parametric estimate of direct taxes}

Using the equation from expression (3) we identify the direct tax $T(X)$ burden as variable influenced by attributes other than income. Thus we formulate a non-parametric estimate of the tax burden as a stochastic function given a worker's wages $X$ such that $E\left[T \mid X+\varepsilon_{i}\right] d X$, where the additional variable behaves as a stochastic determinant of taxes:

\footnotetext{
${ }^{6}$ Unlike the deterministic income tax rates levied upon wage earners by the authorities, this measure seeks to elicit the stochastically formulated decision by each wage earner to garnish the wages to meet that burden. Instead of simply assuming a willingness to increase working hours as a means to increase wages where the tax burden is taken as a given, we are attempting to measure the effect of an increase in a tax burden upon said willingness to work and therefore garnish the income necessary to meet it.

${ }^{7}$ In order to run these regressions we use the module cnpe.ado from Distributive Analysis Stata Package (DASP) v2.3 software programmed by Araar and Duclos (2013).
} 


$$
T=T(X)+\varepsilon_{i}
$$

After running this non-parametric regression of $\mathrm{T}(\mathrm{X})$ with respect to $\mathrm{X}$, we run a similar regression with respect to hours worked $(\mathrm{H})$ such that:

$$
T=T(H)+\varepsilon_{i}
$$

For the sake of robustness of the estimate of the non-parametric relationship between increases in $T$ and $X$ subject to a progressive tax burden structure, we establish the following three axioms:

Axiom 1: Assumptions about preferences in $\mathrm{T}$ : The representative worker is rational and orders his or her preferences according to his or her wage level (X). For an individual $i$ that chooses more $H$ such that he or she gets a higher tax burden $T$, the conditions sufficiently near to $H$ will be reflected upon $T$, if and only if:

$$
\begin{aligned}
\frac{\partial\left(\frac{X_{i}}{H_{i}}\right)}{\partial H_{i}} \geq & 1, \forall X_{i} \rightarrow T(X)>0, \text { sufficient condition, } \\
& \frac{\partial\left(\frac{X_{i}}{H_{i}}\right)}{\partial H_{i}} \leq 1 \text { necessary condition }
\end{aligned}
$$

where the necessary condition in equation (13b) stands for regressivity in $\mathrm{T}$ as long as partial derivative of $\partial\left(X_{i} / H_{i}\right)$ decreases and $\mathrm{H}$ is higher, when $\frac{X_{i}}{H_{i}} \equiv$ $X_{i} \mid \Delta_{1} H_{i} \Rightarrow \Delta^{0} X_{i}$ then, $T\left(X_{i}\right) \leq 1$ should be negative. In our framework, the necessary condition will apply only for level of incomes in the ranges $X_{i} \in\left[0, z^{+}\right]$, where $z^{+}$represents a negative tax (tax credit in our case).

Axiom 2: The representative worker shows monotonicity in his or her decisions: to wit, although a lower tax burden ( $\mathrm{T})$ is preferred, upon an increase on income taxes $T(X)>0$ an increase in working hours will yield a greater tax burden $\frac{\delta T_{i j}}{\delta H_{i j}} \geq 1$.

Proof. Considering a utility of individual $i$ of gender $j$ as a function of wages and hours worked $U_{i j}(X, H)$, with a total derivative such that:

$$
\frac{\delta U_{i j}}{\delta H_{i j}} d H+\frac{\delta U_{i j}}{\delta X_{i j}} d X=0
$$

Solving for $\mathrm{dH} / \mathrm{dX}$ gives us a positive slope that will designate an increase in hours worked $(\mathrm{H})$ in order to increase wages $(\mathrm{X})$, yielding a greater tax burden given the condition that $d H / d X \geq 1$ such that $\frac{\delta T_{i j}}{\delta H_{i j}} \geq 1$.

Axiom 3: Consumption goods are normal goods with respect to the tax burden: Consumption for an individual $i$ of gender $j, C_{i j}$, increases with an increase in wages, $X_{i j}$, and decreases with an increase in tax burdens, $T_{i j}$, if and only if the following derivatives hold:

\footnotetext{
$\frac{\left(\frac{\delta T_{i j}}{\delta X_{i j}}\right)}{\delta X_{i j}}>0, \forall X_{i j} \rightarrow$ Condition of progressiveness and greater tax burden,

$\frac{\left(\frac{\delta C_{i j}}{\delta X_{i j}}\right)}{\delta T_{i j}}<0, \forall T_{i j}>0, X_{i j} \geq z^{+} \rightarrow$ Condition of reduction in consumption with tax increase. 


\subsection{Methodology and formulating the income tax}

We formulate the taxpayers' payments using Mexico's National Statistics Institute's (INEGI, by its initials in Spanish) Household Income and Expenditure Survey (ENIGH, by its initials in Spanish). According to its construction, the information is associated with three units of analysis (dwelling, households and household members); in this research we consider individuals whose source of income are wages. This survey offers a detailed description of the sources of income and characteristics of the participants and has been widely used to analyze Mexico's fiscal system (SHCP, 2016; Huesca and Araar, 2016; Lustig et al., 2014; Vargas, 2010). Hence, estimation results can be generalized to the population since the survey is probabilistic as well a representative of the country and its 32 states.

We use the ENIGH database for 2016 and purge the data based on sex, hours worked weekly and age. ${ }^{8}$ We limit ourselves to consider only wage earners with their corresponding salaries from their main occupations, expressed in Mexican pesos at current prices - i.e., variable $\mathrm{N}$ in equation (1). Further, we also only consider those individuals that have quoted a social security scheme, guaranteeing their formality and thus corroborating the corresponding income tax payments have been made. ${ }^{9}$ Table A.1 in the annex shows the sources of appointment used in the survey.

We apply the corresponding fiscal rules in the survey according to the reconstruction of the fiscal system described in equation (1). The unit of analysis is the individual wage earner, not the household. Thus the ENIGH 2016 survey indicates that a total of 44,834 individuals represent 22.1 million wage earners. This data represents 69 percent of the real census of taxpayers enrolled in SHCP, which reaches a grand total of 32.2 million as of august of 2016 (SAT, 2017). ${ }^{10}$

The fiscal system features eleven distinct income tax rates for 2016. An annual fee must be paid at each rate according to a corresponding fixed quota denominated in Mexican pesos to the order of $[0.00,114.24,2,966.76,7,130.88,9,438.60,13,087.44,39,929.04$, $73,703.40,180,850.80,260,850.84,940,850.76]$. The marginal income tax rates ranged from 1.92 percent to 35 percent (see figure 1). ${ }^{11}$ Also, according to the income tax law in Mexico, workers with annual wages lower than 88,587.96 per year are entitled to receive a tax credit which is compensated to PIT liability (which is alike to an earned income tax credit programs -EITC- in the United States or other OECD countries). ${ }^{12}$ Hereafter, this paper will make reference to Mexican tax credits as EITC. Therefore, the annual amounts of EITC were $[4,884.24,4,881.96,4,879.44,4,713.24,4,589.52,4,250.76,3,898.44,3,535.56$, $3,042.48,2,611.32]^{13}$

\footnotetext{
${ }^{8}$ We exclude child labor from estimations.

${ }^{9}$ We incorporate social security payments only as a means to formulate individuals' gross salaries. We generate a social security variable to capture the corresponding social security fees for each worker in the sample, creating a category for the sort of social security affiliation for all the individuals. Drawing from the sources of income as well as the social security system, we appoint social security fees through a proxy variable for workers by mandatory scheme and the average rate of total contributions made by employers and employees. This is the grand total of the rate of contribution of all the sectors of insurance. (See table A.1 in the appendix.)

${ }^{10}$ See the descriptive statistics in table A.2 in the appendix for further detail.

${ }^{11} \mathrm{It}$ is worth mentioning that ENIGH survey captured only 3 observations with wages exceeding 3 million Mexican pesos annually. These values were not included in figure 1, which is why the tax bracket for 35 percent is not observed.

${ }^{12}$ In United States (US), EITC operates different than in Mexico; i.e., taxpayers must accomplish certain requirements -besides their low income condition- and fill a claiming procedure for a tax return. In Mexico, EITC is only based on earnings.

${ }^{13}$ For instance, in 2016 if a worker earned one minimum wage, annual PIT liability was $\$ 1,439$ Mexican pesos, while EITC was $\$ 4,879$. As a result, the low wage earner received a net EITC of $\$ 3,440$ (i.e., the difference is added to the salary).
} 
Figure 1. Marginal income tax brackets in Mexico, 2016

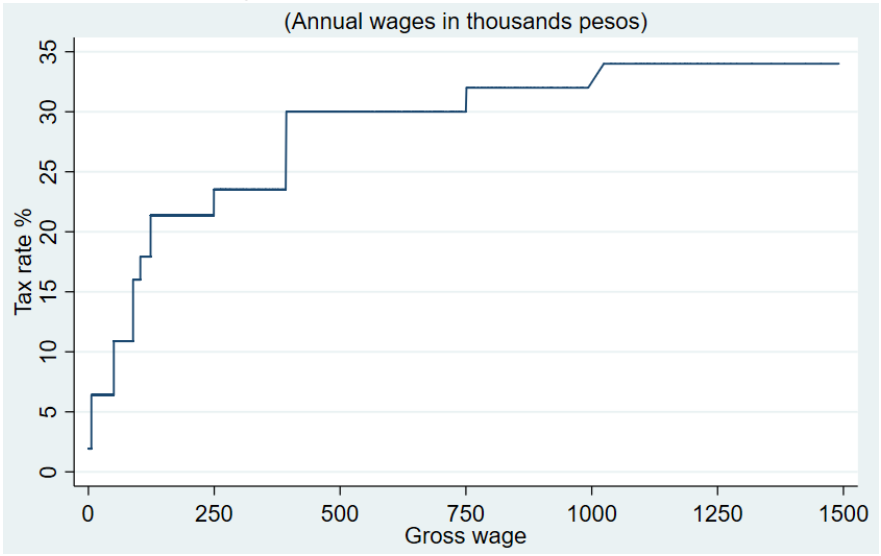

Source: Author's elaboration using data from ENIGH survey for 2016

\section{Empirical Results}

Figure 2 shows the distribution of the income tax burden for 2016, indistinctly from worker gender. ${ }^{14}$ For the sake of robustness we have formulated our estimates with a 95 percent confidence interval. These confidence intervals are shown as narrow bands in both graphs in this figure as a result of using non-parametric techniques as well as the big sample in the survey. Recalling equation (7) we observe an increasing PIT payments over the entire annual wages, as a result of PIT progression. Likewise, the negative income tax values for annual wages lower than 63,000 Mexican pesos capture the effect of the tax credit (see left graph in figure 2.)

These results coincide with the marginal changes registered as described by the equation in expression (9). The right panel graph in figure 2, shows the extent of which a monetary unit increase in gross wages yields an increase in the income tax burden for the entire distribution of wage earners' incomes. We observe a greater tax burden on annual wages exceeding 750 thousand pesos. For annual wages of a million and a half Mexican pesos the effective marginal rate reached 25 percent.

Figure 2. Personal income tax by gross wages in Mexico, 2016

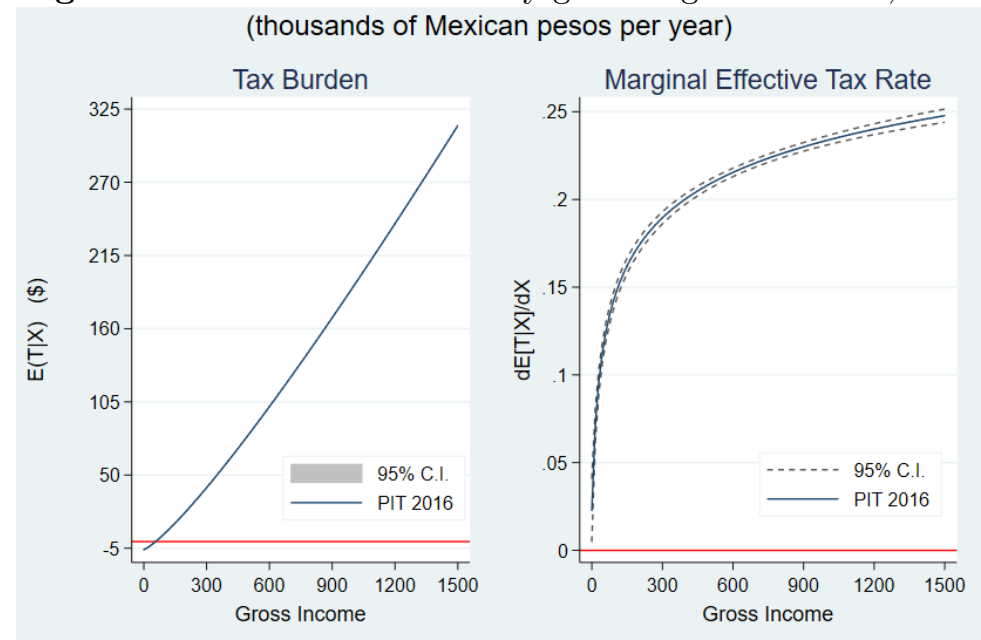

Source: Author's elaboration using data from ENIGH survey for 2016

\footnotetext{
${ }^{14}$ We have bounded our estimates to an annual income level of a million and a half Mexican pesos. Past that income level there are no strong trends due to presence of outliers, with only twenty observations. This calculation does not affect tax burdens, only a graphical spectrum that bounds the range of incomes.
} 
Figure 3 shows how the EITC benefits people with a monthly wage less than $7,382.33$ Mexican pesos (3.34 minimum wages) or 88,587.96 per year. This validates the necessary condition in expression (13b) of Axiom 1, where workers with insufficient income and below the threshold, do not contribute to a greater share of the tax payments. To wit, by using non-parametric techniques we were able to observe a higher horizontal inequity in the tax system. The top 60th percentile of wage earners bears the brunt of the income tax payments. Again, confidence intervals are narrow as a signal of strong robustness in the estimations across all the percentiles of population.

Recall that Mexican income tax law reduce income tax liability for low wage earners, that is, PIT is compensated with an EITC. Furthermore, if the worker is eligible to receive the credit, the employer must pay to the worker by adding the amount of the EITC to the salary (i.e., it serves as a subsidy). In this regard, the Mexican law protects low wage earners from being affected by the tax system by worsening their economic status. However, such measure reduces public revenues. The magnitude of EITC effect reveals the existence of an enormous low-wage labor market. It is urgent to stablish measures that lead to a salary increase by taking into account real labor productivity; consequently, the taxpayer base would be expanded.

Figure 3. Personal income tax by wage percentile in Mexico, 2016

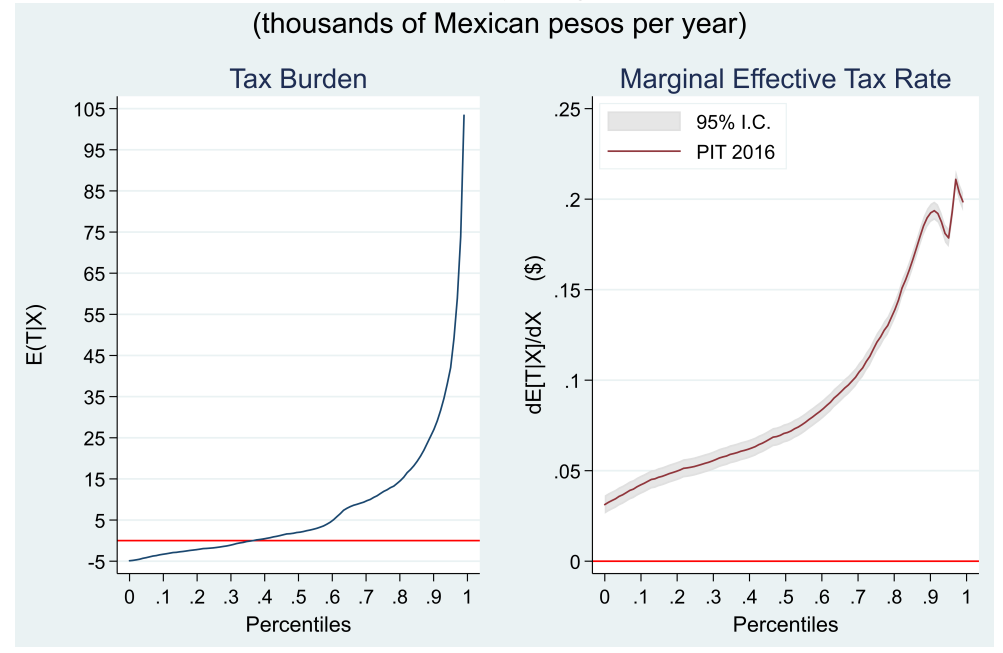

Source: Author's elaboration using data from ENIGH survey for 2016

This evidence matches previous studies' findings about a high incidence of horizontal inequity in tax contributions in Mexico (Huesca and Araar, 2016). According to Vargas (2010), the incidence of PIT on wages has worsened in 2002 compared to 1984, where 90 percent of the tax burden was paid by the last three deciles, due to the low wages of the counterpart deciles of the contributors who received the EITC. In subsequent research, Flores, Valero, Chapa and Bedoy (2005) found that the low wages overtake the informal sector in Mexico; if the corresponding PIT rates are applied, informal workers would potentially represent a fiscal burden -due to EITC eligibility-, instead of been a source of tax collection. Mexican results are alike to Guatemala, where 73 percent of employees are exempted of PIT payment (Díaz, Garcimartín and Ruiz-Huerta, 2010).

Further analysis of the marginal changes in income tax rates with respect to gross wages shows positive change for the entire income distribution. These marginal changes remain near zero up until the 30th percentile by virtue of the pro-poverty effect of the tax system for this segment of the population (Huesca and Llamas, 2016). On the contrary, the effective tax rate for the top 1 wage earners is close to 20 percent, even though statutory tax rate is 35 percent. 
Figure 4 shows the wage dispersion for four workday categories: a) below than halftime (up to 19 hours a week), b) half-time up to less than full-time (20 to 34 hours a week), c) full-time (35 to 48 hours a week), and d) above full-time (more than 48 hours a week). We observe that 75 percent of wage earners (inside the box) receives up to 2,500 Mexican pesos a week for all the workday categories. It is worth noticing that people with weekly wages of 1,703 Mexican pesos receive an EITC, showing evidence of low wage levels for a great portion of the people in Mexico regardless of the working hours (see horizontal line in Figure 4).

Intuitively, from figure 4 it would be expected to observe larger box plots while increasing working hours, thus gross incomes per week would improved from a higher workday. However, data structure reflects that a Mexican representative wage earner receives low salary regardless higher working hours, that is, it reveals a labor market with low wages. The wage earning tax base that pays the bulk of the tax income and does not receive an EITC is mostly represented by the distance of in the top of the box with respect to the adjacent line above along with the corresponding outliers.

Figure 4. Dispersion of gross wages per hours worked in Mexico, 2016

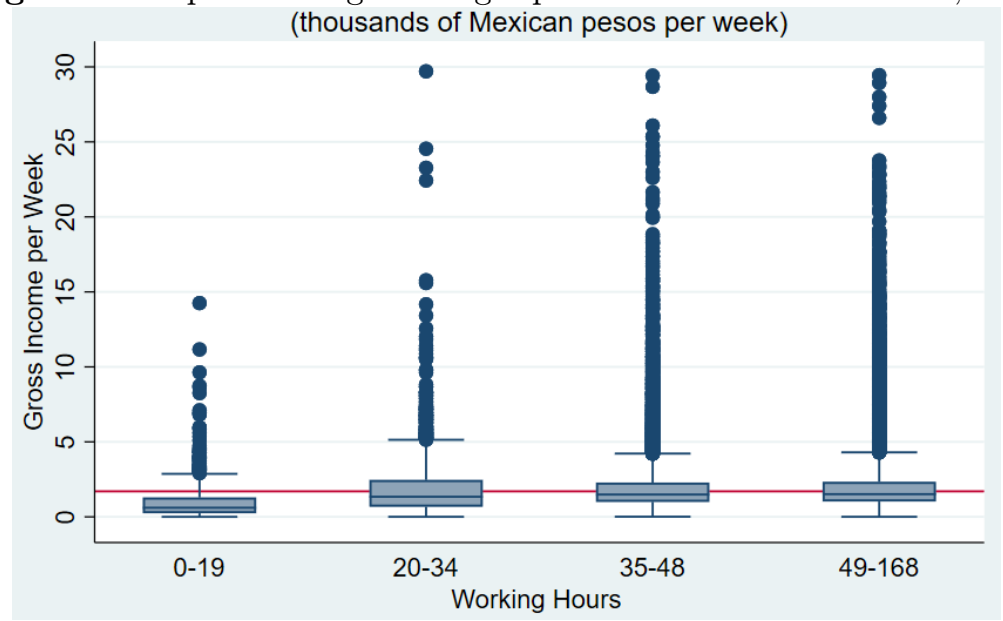

Source: Author's elaboration using data from ENIGH survey for 2016

Figure 5 shows the estimated wage levels by sex as well as the change in marginal rates by hours worked. We observe that men have greater wages than women. The location of the tangency is located in the 45-50 weekly hours as a result of low wages even above of full time workdays. Comparing the locations of tangency, we observe a faster rate of wage increase for men than woman. Thus potentially implying a greater gender inequality regardless of the hours worked.

The bottom panel in Figure 5 show the marginal changes in wages with respect to hours worked. This graph shows a crossing of these curves for men and women as a result of a change in the sign of their partial derivatives of wages with respect to hours worked. We could infer the men's wages reaches its highest level when work hours exceed 50 hours a week.

According to equations in expressions (8) and (10), we simultaneously show the estimates for the weekly tax burden by sex and hours worked. Figure 6 reveals that men make greater contributions towards the income tax than women. Furthermore, the negative tax burden (EITC) for reduced workdays is greater for women than men, as a result of received low wages, stands out (see upper panel of figure 6 , the level reached by negative taxes for women with working hours below than 11 hours a week).

The reduced tax contributions reflect low wage levels for both genders, with a greater impact on women. The hypothesis can be proven inasmuch as the income tax payments 
do not reveal a growing tendency from weekly full-time working hours on for both, women and men.

Figure 5. Wages per hours worked in Mexico, 2016

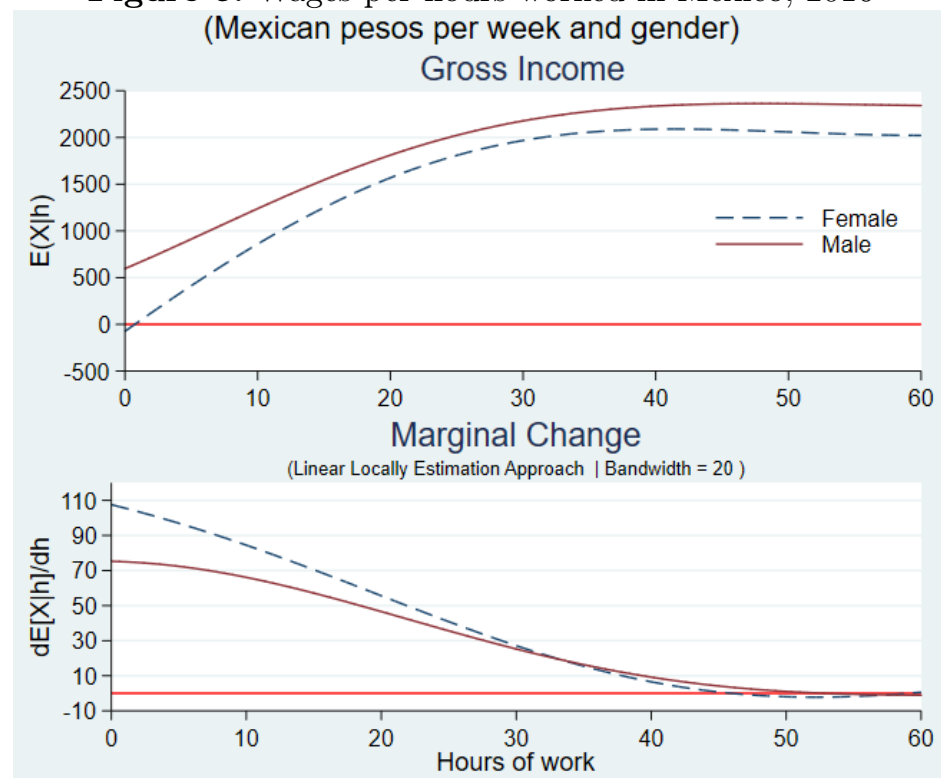

Source: Author's elaboration using data from ENIGH survey for 2016

Figure 6. Personal income tax per hours worked in Mexico, 2016

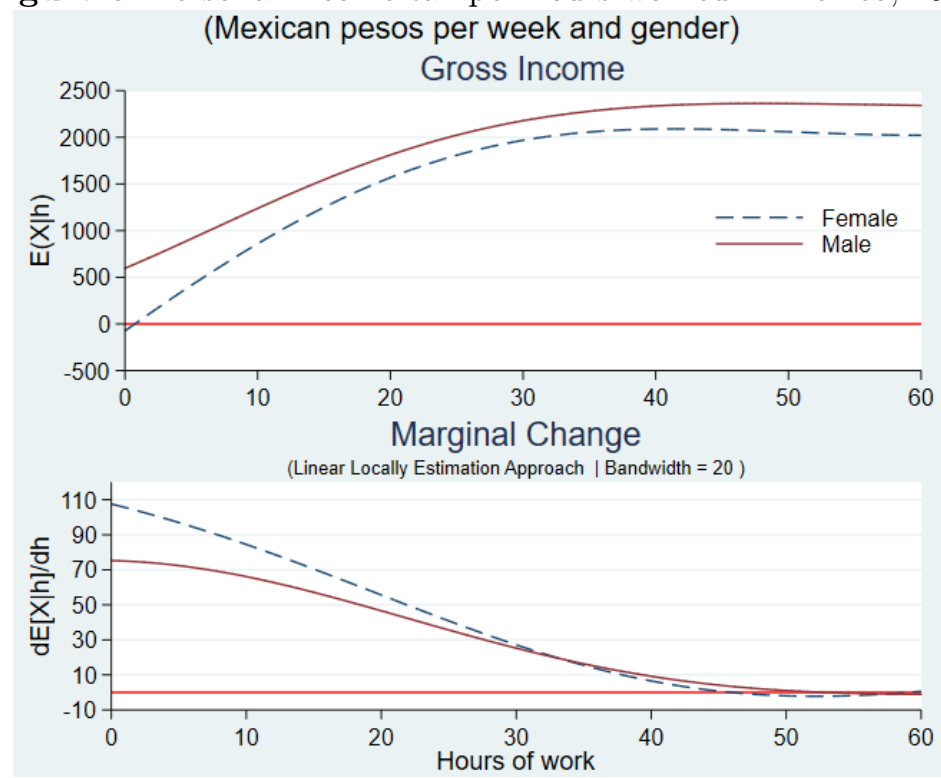

Source: Author's elaboration using data from ENIGH survey for 2016

According to equations (8) and (10), estimates in Figure 6 depicts that in spite of working longer hours, the workdays do not translate into incomes able to contribute more direct taxes to the public purse - in line with Axiom 2, $\frac{\partial T_{i j}}{\partial H_{i j}} \geq 1$ and according to utility function in expression (14), where marginal changes equal zero. The marginal changes in 2016 show a declining trend for both genders (around 48 hours for males and 43 for females). Thus a wage earner facing longer workdays in Mexico will not necessarily pay more taxes. 
According to previous evidence, despite of high progressiveness of income tax in Mexico, Axiom 3 and expression (15a) is confirmed and expression (15b) shows grounds for unraveling the low purchasing power labor market. This market is the recipient of EITC and contributes less to the payment of direct taxes in Mexico, indistinctly from gender and regardless of an increase in hours worked.

\section{Concluding Remarks}

We revise Mexican wage taxation using non-parametric techniques with microdata. Therefore, aspects such as tax incidence, progressivity and tax credits on one hand, as well as wage levels and tax burden by sex and hours worked on the other are analyzed without setting a functional relationship. Our analysis shows that Mexico's wage and labor policies have an effect beyond the fiscal realm in spite of the structural improvements to the income tax - i.e., a high horizontal inequity and the limited efficiency of tax collection. We are able to prove our stated null hypothesis. Namely, income tax payments do not show an increasing trend in 2016 even with an increase in a wage earner's working hours.

Although personal income tax in Mexico is highly progressive, our estimates revealed how the top 1 percent wage earners bears an effective marginal tax rate of 20 percent, which is 15 percentage points below from statutory tax rate. Furthermore, 75 percent of the wage earners reaches a weekly wage of up to 2,500 Mexican pesos (120,000 annually). However, the 40 percentile are the main negative tax burden (EITC) recipients which benefits workers with yearly wages of 88,587.96 Mexican pesos.

The direct tax system redistributes the EITC into a high portion of low-income contributors. Our estimates show a high level of horizontal inequity in Mexico as long as the top 60 percent of wage earners contribute to the payments of the personal income tax. Tax credit is not exclusive for employees with reduced workdays, ever since low salaries goes beyond of full-time working hours in this country.

Mexican wage earner facing longer workdays will not necessarily pay more taxes, as long as negative marginal changes from personal income tax payments are observed (Figure 6). The diminishing marginal tax burdens for workers with longer working hours, could be attributed to diverse array of low paying jobs with no substantial contributions to personal income tax. We also find a higher tax burden for men than women based on hours worked, regardless their income. There is a gender wage difference, where marginal income tax rates for men are higher than women for working hours beyond part-time. Moreover, the EITC for reduced workdays is greater for women than men, as a result of received low wages.

Our assessment is that a labor market with depressed wages and low purchasing power will not contribute to a steadily strengthening of the public revenues. A representative Mexican wage earner receives low salary regardless higher working hours. Thusly, this research sets the norm for future studies linking tax collection and tax burden by workdays and occupations. It also allows us to extend our analysis to databases that include the remaining tax figures (i.e. Value added and excise taxes). Overall, Mexico's tax credits act as a compensation wage for poverty. This will therefore, continue to yield a limited income tax base, resulting in insufficient public funds.

\section{Referencias}

Alberro, J. (2018), Costo fiscal de erradicar la pobreza extrema en México introduciendo un impuesto negativo al ingreso, Estudios y Perspectivas, Series de la CEPAL, México, April 2018.

Araar, A. (2008), "Social Classes, Inequality and Redistributive Policies in Canada", working paper 08-17, CIRPÉE Université Laval, Canada, August 2008.

Araar, A. and Duclos, J.-Y. (2013), DASP: Distributive Analysis Stata Package, User Manual, Version 2.3, PEP, CIRPÉE and World Bank, Université Laval, June. 
Castañeda, V. (2016), "La globalización y sus relaciones con la tributación, una constatación para América Latina y la OCDE", Cuadernos de Economía, Vol. 35 No. 68, pp. 379-406.

ECLAC (2016), Economic Survey of Latin America and the Caribbean 2016: The 2030 Agenda for Sustainable Development and the challenges of financing development, CEPAL LC/G.2684-P, Santiago.

Davidson, R. and Duclos, J.-Y. (1997), "Statistical Inference for the Measurement of the Incidence of Taxes and Transfers", Econometrica, Vol. 65 No. 6, pp. 1453-1465.

Díaz de Serralde, S., Garcimartín, C., and Ruiz-Huerta, J. (2010). La paradoja de la progresividad en países de baja tributación: el impuesto a la renta en Guatemala. Revista CEPAL.

Duclos, J.-Y. and Tabi, M. (1996), "The measurement of progressivity, with an application to Canada", The Canadian Journal of Economics/Revue canadienne d'Economique, Vol. 29 (Special Issue Part I), pp. s165-s170.

Duclos, J.-Y. and Araar, A. (2006), Poverty and Equity. Measurement, Policy, and Estimation with DAD, Springer, Otawa, Canada.

Eissa, N., Hoynes, H. W. (2004). Taxes and the labor market participation of married couples: the earned income tax credit. Journal of public Economics, 88(9-10), 1931-1958.

Flores, D., Valero, J. N., Chapa, J. C., and Bedoy, B. (2005). El sector informal en México: medición y cálculo para la recaudación potencial. Ciencia UANL, 8(4), pp. 490-494.

Härdle, W. (1990), Applied Nonparametric Regression, Cambridge University Press.

Hayo, B., Uhl, M. (2015). Taxation and labour supply: Evidence from a representative population survey. Journal of Macroeconomics, 45, 336-346.

Huesca, L. and Serrano, A. (2005), "Impacto Fiscal Re-distributivo Desagregado del Impuesto al Valor Agregado en México: Vías de reforma", Investigación Económica, Vol. LXIV No. 253, pp. 89-122.

Huesca, L. and Araar, A. (2016), "Comparison of the fiscal system progressivity over time: Theory and application in Mexico", Estudios Económicos, Vol. 31, No. 1, pp. 3-45.

Huesca L. and Llamas, L. (2016), "Testing for Pro-Poorness of Growth through the Tax System: The Mexican Case", Journal of Reviews on Global Economics, Vol. 5, pp. 101-115.

INEGI (2017), Encuesta Nacional de Ingresos y Gastos de los Hogares 2016, Microdata, available at: http://inegi.org.mx

Joumard, I., Pisu, M. and Bloch, D. (2012), "Less income inequality and more growth - are they compatible? Part. 3. Income redistribution via taxes and transfers across OECD Countries," OECD Economics Department Working Paper, No. 926, OED Publishing, Paris. DOI: 10.1787/5k9h296b1zjf-en

Keane, M. P. (2011). Labor supply and taxes: A survey. Journal of Economic Literature, 49(4), pp. 961-1075.

Lustig, N., Pessino, C. and Scott, J. (2014), "The impact of taxes and social spending on inequality and poverty in Argentina, Bolivia, Brazil, Mexico, Peru, and Uruguay: Introduction to the special issue", Public Finance Review, Vol. 42 No. 3, pp. 287-303.

Mastrogiacomo, M., Bosch, N. M., Gielen, M. D., Jongen, E. L. (2017). Heterogeneity in labour supply responses: Evidence from a major tax reform. Oxford Bulletin of Economics and Statistics.

Meghir, C., Phillips, D. (2010). Labour supply and taxes. In: Adam, S., Besley, T., Blundell, R., Bond, S., Chote, R., Gammie, M., Johnson, P., Myles, G., Poterba, J. (Eds.), Dimensions of Tax Design: The Mirrlees Review. Oxford University Press, Oxford, pp. 202-274.

Musgrave, R. (1990), "Horizontal equity, once more", National Tax Journal, pp. 113-122.

Nichols, A., Rothstein, J. (2015). The earned income tax credit (EITC) (No. w21211). National Bureau of Economic Research.

OECD (2005), Taxing Working Families a Distributional Analysis, OECD Tax Policy Study No. 12, OECD Publishing, Paris. DOI: http://dx.doi.org/10.1787/9789264013216-en

Paturot, D., Mellbye, K. and Brys, B. (2013), "Average Personal Income Tax Rate and Tax Wedge Progression in OECD Countries", OECD Taxation Working Papers, No. 15, OECD Publishing, Paris. DOI:10.1787/5k4c0vhzsq8v-en

Perrote, I., Rodríguez, J.G. and Salas, R. (2002), "Una descomposición no paramétrica de la redistribución en sus componentes vertical y horizontal: una aplicación al IRPF", working paper 11/02, Instituto de Estudios Fiscales, Madrid.

Rodríguez, J.J. (2014), "Efectos de las políticas tributaria y fiscalizadora sobre el tamaño del sector informal en Colombia", Cuadernos de Economía, Vol. 33 No. 63, pp. 487-511.

SAT (2017), "Cifras SAT Padrón por tipo de contribuyente", available at: http://www.sat.gob.mx/ cifras_sat/Paginas/datos/vinculo.html?page=giipTipCon.html (accessed 21 November 2017).

Scott, J. (2014), "Redistributive impact and efficiency of Mexico's fiscal system", Public Finance Review, Vol. 42 No. 3, pp. 368-390.

SHCP (2016), "Distribución del pago de impuestos y recepción del gasto público por deciles de hogares y personas. Resultados para el año de 2014", available at: http://www.hacienda.gob.mx/INGRESOS/ ingresos_distribucion_pago/IG_2016(ENIGH2014).pdf (accessed 1 March 2016).

Scholz, J. (1994). The earned income tax credit: participation, compliance, and antipoverty effectiveness. National Tax Journal, Vol. 47 No. 1, 63-87.

Vargas, C. (2010), “¿Es redistributivo el sistema fiscal en México? La experiencia de 1984-2002”, Estudios Sociales, Vol. 18 No. 35, CIAD, Hermosillo, pp. 54-97. 


\section{Appendix: Gross Wage Definition and Data}

Table A.1. Formulation of the gross wage for income tax simulation

\begin{tabular}{ll}
\hline Tax burden a & Indicators \\
\hline Personal income tax & - Direct tax on income (respective brackets and quotas in 2016) \\
& - Tax credit (respective quotas) \\
\hline \multirow{2}{*}{ Employer's social security contributions } & -By social security \\
& -For contributory pensions \\
& -For public housing (Government housing funds) \\
\hline \multirow{2}{*}{ Employee's social security contributions } & -By social security \\
& -For contributory pensions \\
& -For public housing (Government housing funds) \\
\hline
\end{tabular}

Note: /a Obtained through imputed simulation methods.

Source: Authors' elaboration based on information from ENIGH survey and the Secretariat of Finance and Public Credit (SHCP) sources for 2016.

Table A.2. Yearly descriptive statistics for 2016.

\begin{tabular}{lccccc}
\hline Variable & Observations & Media & Desv. Std. & Min & Max \\
\hline 2016 & & & & & \\
Gross wage (X) & $22,105,069$ & 114,109 & 127,925 & 123 & $3,655,531$ \\
Net wage (N) & $22,105,069$ & 101,869 & 100,154 & 5,002 & $2,720,564$ \\
Income tax (T) & $22,105,069$ & 9,458 & 24,933 & $-4,882$ & 845,843 \\
Social security payments (SSC) & $22,105,069$ & 2,782 & 3,119 & 3 & 89,124 \\
Hours worked & $22,105,069$ & 49 & 16 & 1 & 189 \\
Age & $22,105,069$ & 38 & 12 & 16 & 95 \\
Women & & & & & \\
Gross wage (X) & $8,093,439$ & 103,417 & 109,492 & 123 & $1,665,590$ \\
Net wage (N) & $8,093,439$ & 93,233 & 86,645 & 5,002 & $1,271,739$ \\
Income tax (T) & $8,093,439$ & 7,662 & 20,407 & $-4,882$ & 353,242 \\
Social security payments (SSC) & $8,093,439$ & 2,521 & 2,670 & 3 & 40,608 \\
Hours worked & $8,093,439$ & 44 & 15 & 1 & 188 \\
Age & $8,093,439$ & 38 & 11 & 16 & 83 \\
Men & & & & & \\
Gross wage (X) & $14,011,630$ & 120,285 & 137,071 & 144 & $3,655,531$ \\
Net wage (N) & $14,011,630$ & 106,858 & 106,866 & 5,022 & $2,720,564$ \\
Income tax (T) & $14,011,630$ & 10,495 & 27,152 & $-4,882$ & 845,843 \\
Social security payments (SSC) & $14,011,630$ & 2,933 & 3,342 & 4 & 89,124 \\
Hours worked & $14,011,630$ & 52 & 16 & 1 & 189 \\
Age & $14,011,630$ & 39 & 12 & 16 & 95 \\
\hline
\end{tabular}

\footnotetext{
Source: Authors' elaboration based on information from ENIGH survey for 2016.
} 